\title{
Efektivitas Ekstrak Daun Afrika (Vernonia amygdalina) Secara Topikal Untuk Reepitelisasi Penyembuhan Luka Insisi Pada Tikus Putih (Rattus novergicus)
}

\section{(EFFECTIVITY OF BITTER LEAF EXTRACT (Vernonia amygdalina) TOPICALLY TO RE-EPITHELIALIZATION INCISION WOUND HEALING IN RATS (Rattus novergicus))}

\author{
Rizki Putrianirma ${ }^{1 *}$, Nusdianto Triakoso ${ }^{2}$, Maya Nurwartanti Yunita ${ }^{3}$, Ira Sari \\ Yudaniayanti ${ }^{2}$, Iwan Sahrial Hamid ${ }^{4}$, Faisal Fikri ${ }^{4}$ \\ ${ }^{1}$ Bachelor of Veterinary Medicine, \\ ${ }^{2}$ Department of Veterinary Clinic, \\ ${ }^{3}$ Department of Veterinary Pathology, \\ ${ }^{4}$ Department of Basic Veterinary Science, \\ Faculty of Veterinary Medicine, Universitas Airlangga, \\ UNAIR C-Campus Mulyorejo, Surabaya, Jawa Timur, Indonesia, 60115 \\ Telp. (031)5993016, Fax. (031)5993015 \\ *Corresponding author: rizki.putrianirma-2014@ @ fkh.unair.ac.id
}

\begin{abstract}
Abstrak
Penelitian ini bertujuan untuk mengetahui pengaruh dan hubungan konsentrasi pemberian ekstrak daun afrika (Vernonia amygdalina) secara topikal terhadap efektivitas penyembuhan luka dan reepitelisasi penyembuhan luka insisi pada tikus putih. 20 tikus putih jantan di kelompokkan secara acak dibagi dalam 5 kelompok perlakuan yaitu P0 (vaseline + adeps lanae), P1 (povidone iodine), P2 (salep ekstrak daun afrika 16,8 $\%$ ), P3 (salep ekstrak daun afrika $28 \%$ ), dan P4 (salep ekstrak daun afrika 39,20\%). Penelitian ini dilakukan selama 14 hari dengan mengukur dengan skor reepitelisasi pada sediaan histopatologi kulit luka insisi yang telah diberi perlakuan. Hasil penelitian tidak menunjukkan perbedaan yang nyata antara kontrol dengan perlakuan $(\mathrm{p}>0,05)$. Perlakuan dengan ekstrak daun afrika (Vernonia amygdalina) tidak menunjukkan reepitelisasi yang berbeda dengan perlakuan kontrol.
\end{abstract}

Kata kunci: Vernonia amygdalina, penyembuhan, luka, insisi, reepitelisasi

\begin{abstract}
This study aims to determine the effect and the relation between the concetration of bitter leaf (Vernonia amygdalina) extract topically and the effectiveness of wound healing and re-epithelialization incision wound healing in rats. 20 male rats are grouped randomly divided into 5 groups, namely PO (vaseline + adeps lanae), P1 (povidone iodine), P2 (bitter leaf extract ointment 16.8\%), P3 (bitter leaf extract ointment $28 \%$ ), and P4 (bitter leaf extract ointment 39.20\%). This research was carried out for 14 days by measuring the reepithelialization scores on histopathologic preparations of treated wound skins. The results showed no significant difference between the control treatment $(p>0.05)$. Treatment with bitter leaf extract (Vernonia amygdalina) showed no different re-epitheliazation than control treatment.
\end{abstract}

Key words: Vernonia amygdalina, healing, wounds, incisions, re-epithelialization

\section{PENDAHULUAN}

Luka merupakan hilangnya atau rusaknya sebagian jaringan tubuh. Keadaan ini sering dialami setiap hewan maupun manusia, baik dalam tingkat keparahan yang ringan, sedang, ataupun berat (Putri dkk., 2014). Luka sering terjadi pada kulit yang menyebabkan kerusakan pada epitel kulit atau terputusnya kesatuan struktur anatomi normal pada jaringan akibat trauma. Luka insisi dapat terjadi karena disengaja (luka operasi) atau tidak disengaja (luka eksidental) akibat benda tajam (Nangoi, 2010 dalam Nabeela, 2017). 
Menurut Putri dkk. (2014), pengobatan secara kimiawi sebagai antiseptik yang sering digunakan untuk penyembuhan luka salah satunya adalah Povidone iodine. Povidone iodine dapat juga mencegah inflamasi namun penggunaan Povidone iodine $10 \%$ dapat menghambat pembentukan fibroblas.

Menurut World Health Organization (WHO) dalam Putri dkk., (2014), 80\% di negara Asia dan Afrika menggunakan cara pengobatan tradisional yaitu obat herbal karena lebih murah, mudah didapat dan efek samping rendah.

Penelitian Nafiu et al., (2016) menggunakan perasan Daun Afrika (Vernonia amygdalina) dapat menyembuhkan luka eksisi dan memiliki manfaat diantaranya sebagai antibakteri, antiinflamasi, analgesik, dan antioksidan karena didalamnya memiliki kandungan flavonoid, alkaloid, saponin dan tanin. Menurut penelitian Eyo et al., (2014) ekstrak methanol 50\% Daun Afrika (Vernonia amygdalina) lebih efektif dalam menyembuhkan luka eksisi pada tikus putih dari segi waktu luka menutup serta eksudasi yang minimal

Kulit sangat berperan penting dalam kehidupan hewan maupun manusia, antara lain sebagai pengatur keseimbangan air dan elektrolit, sensasi, termoregulasi, perlindungan dari sinar dan berfungsi dalam perlindungan lingkungan luar termasuk parasit dan mikroorganisme, maka sangat penting mengembalikan kesembuhannya dengan segera (Brunicardi, 2010 dalam Budiman dkk., 2015).

Penelitian ini bertujuan untuk mengetahui pengaruh pemberian ekstrak daun afrika (Vernonia amygdalina) secara topikal terhadap efektifitas penyembuhan luka insisi pada tikus putih dan untuk mengetahui hubungan antara konsentrasi ekstrak daun afrika (Vernonia amygdalina) terhadap reepitelisasi penyembuhan luka insisi pada tikus putih.

\section{METODE PENELITIAN}

\section{Ijin Etik Hewan Coba}

Penelitian ini telah melalui uji etik penelitian hewan coba dengan sertifikat etical clearanve nomor 782-KE.

\section{Alat dan Bahan Penelitian}

Bahan yang digunakan pada penelitian ini yaitu 20 ekor tikus putih jantan (Rattus norvegicus) yang berumur tiga sampai empat bulan dengan berat badan 150-200 gram. Tikus dipelahara dalam kandang yang diberi serbuk kayu untuk menjaga suhu tetap optimal. Povidone iodine, basis salep, dan salep ekstak daun Afrika digunakan sebagai terapi luka insisi kemudian luka dibalut dengan kassa dan plaster penutup luka.

Peralatan yang digunakan pada penelitian ini yaitu temat minum, pencukur rambut tikus, scalpel, blade, spuit tuberculin, spatula kecil untuk pengaplikasian obat secara topikal, glove untuk menjaga tangan tetap steril, kapas, penutu luka, gunting,peralatan bedah minor untuk pengambilan jaringan kulit, serta mikroskop trinokuler.

\section{Pembuatan Salep Vernonia amygdalina}

Pembuatan sediaan salep ekstrak daun afrika pembuatan salep (unguentum) menurut Agoes dalam Saputri dan Arsitha (2017) yaitu membuat basis salep dengan vaseline flavum dan adeps lanae dengan $85 \%$ vaseline flavum dan $15 \%$ adeps lanae, mengukur dan menimbang vaseline dan adeps lanae dengan berat akhir 30 gram lalu dihomogenkan dengan mortar, menimbang ekstrak Daun Afrika 16,8 gram lalu ditambahkan basis salep hingga berat 10 gram lalu dihomogenkan dengan mortar, mengulangi untuk konsentrasi 2,8 gram dan 3,92 gram, kemudian menyimpan salep pada pot salep steril.

\section{Perlakuan}

Penelitian dilakukan menggunakan Rancangan Acak Lengkap (RAL). Tikus dibagi menjadi lima kelompok perlakuan, yaitu P0 (diberi perlakuan vaseline + adeps lanae), P1 (povidone iodine), P2 (ekstrak daun afrika 16,8\%), P3 (ekstrak daun afrika $28 \%$ ), P4 (ekstrak daun afrika 39,2\%). Tiap perlakuan terdiri dari empat ekor tikus.

Tikus putih dibius total dengan ketamin 50 $\mathrm{mg} / \mathrm{kgBB}$ dan xylazine $5 \mathrm{mg} / \mathrm{kgBB}$ sebagai sedatif dengan cara intramuskuler (Suckow et al., 2006). Kemudian punggung tikus putih 
dicukur seluas $3 \mathrm{~cm}$ x 2,5 cm. Pada daerah tersebut diinsisi dengan scalpel dengan panjang $2 \mathrm{~cm}$ kedalaman hingga subkutan dengan cara kulit dicubit dengan pinset menggunakan tangan sebelah kiri dan tangan kanan menginsisi dengan scalpel yang dipegang oleh tangan kanan. Insisi dilakukan dengan scalpel ke arah kaudal (Asali, 1993 dalam Wibawati, 2012).

\section{Metode Skoring}

Perlakuan dilakukan sebanyak sekali sehari selama 14 hari dan dilanjutkan euthanasia dan pengambilan jaringan kulit untuk pemeriksaan histopatologi. Menurut Sastrawan dkk., (2016) pengamatan histopatologi dengan menilai reepitelisasi menggunakan skor berikut:

\begin{tabular}{cl}
\hline Skor & \multicolumn{1}{c}{ Parameter Ketebalan Epitel } \\
\hline 1 & $\begin{array}{l}\text { Reepitelisasi } \\
\text { normal }\end{array}$ \\
2 & $\begin{array}{l}\text { Reepitelisasi } 25-50 \% \text { bagian luka dari } \\
\text { normal }\end{array}$ \\
3 & $\begin{array}{l}\text { Reepitelisasi } \\
\text { normal }\end{array}$ \\
& $\begin{array}{l}\text { Reepitelisasi }>75 \% \text { bagian luka dari } \\
\text { normal }\end{array}$ \\
\hline
\end{tabular}

\section{Analisis Data}

Data dianalisis menggunakan SPSS Versi 22 meliputi uji nonparametrik Kruskal-Wallis kemudian uji lanjutan menggunakan uji MannWhitney $\mathrm{U}$ jika terdapat perbedaan yang nyata $(\mathrm{p}<0,05)$.

\section{HASIL DAN PEMBAHASAN}

Pemeriksaan histopatologi dari setiap pengulangan dalam setiap kelompok dinilai skornya dengan mikroskop trinokuler perbesaran 400 kali seperti pada gambar 1 .

Hasil uji nonparametrik Kruskal-Wallis untuk skor reepitelisasi luka insisi tikus putih adalah 0,724 yang menunjukkan tidak adanya perbedaan yang nyata $(\mathrm{p}>0,05)$. Uji data statistik tidak dilanjutkan ke uji Mann-Whitney $U$ karena perbedaan tidak signifikan. Data skor kemudian dilanjutkan dengan menghitung rataan dan simpangan baku seperti pada tabel 1 .

Tabel 1. Rata-rata reepitelisasi pada setiap kelompok perlakuan

\begin{tabular}{lc}
\hline \multicolumn{1}{c}{ Perlakuan } & Rata-rata \pm SB \\
\hline P0 (Vaseline + Adeps Lanae) & $2,00^{\mathrm{a}} \pm 1,414$ \\
P1 (Povidone iodine) & $2,00^{\mathrm{a}} \pm 0,816$ \\
P2 (ekstrak daun afrika 16,8\%) & $2,50^{\mathrm{a}} \pm 1,291$ \\
P3 (ekstrak daun afrika 28 \%) & $1,75^{\mathrm{a}} \pm 1,500$ \\
P4 (ekstrak daun afrika 39,2\%) & $1,50^{\mathrm{a}} \pm 0,577$ \\
\hline
\end{tabular}
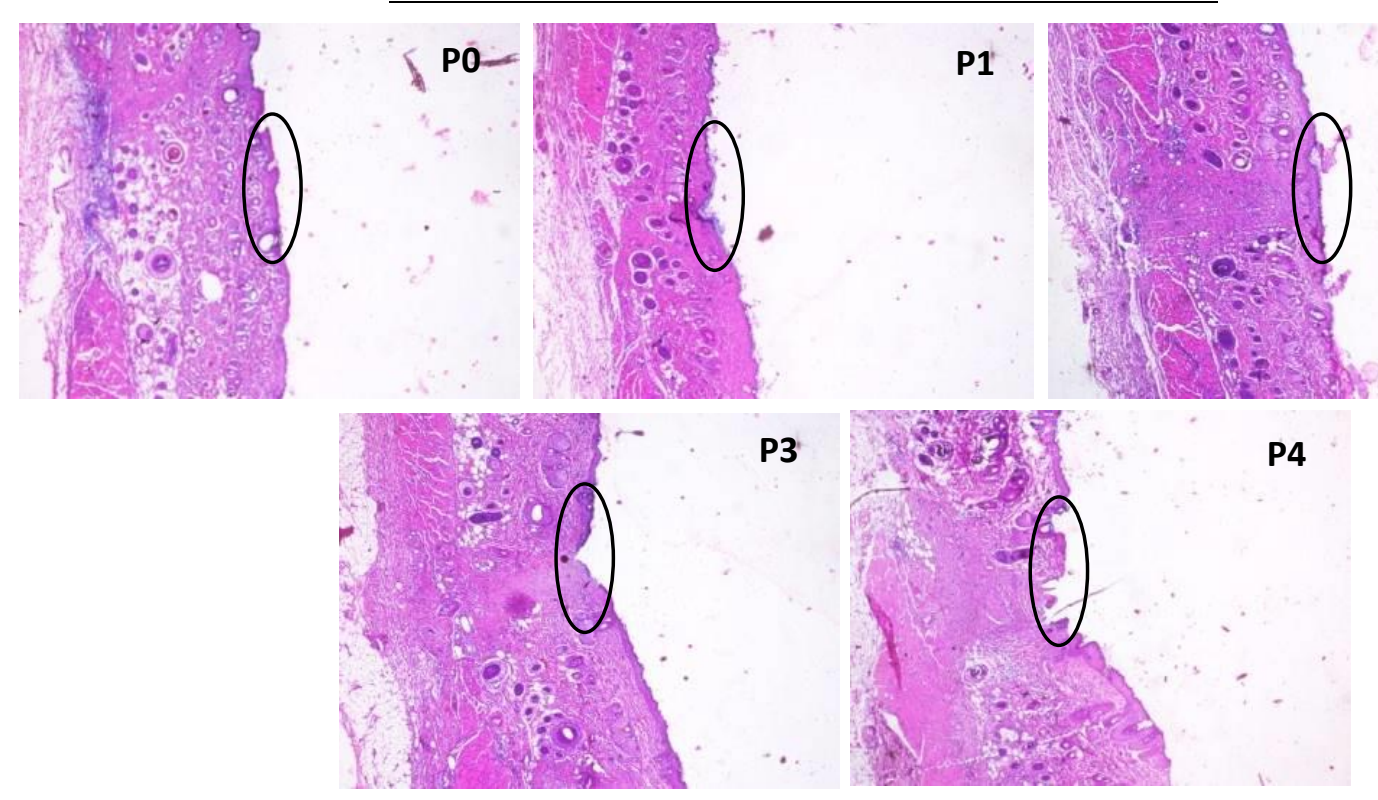

P2

Gambar 1. Gambaran reepitelisasi (lingkaran) pada kulit luka insisi 
Pada pengamatan makroskopis hari ke- 0-4 terjadi proses inflamasi dimana sel-sel dan protein ada dalam darah, sel endotel dan fibroblas mulai berproliferasi untuk membentuk jaringan granulasi pada hari ke- 3-5 yang merupakan tanda awal kesembuhan (Jayalandri dkk., 2016).

Fase proliferasi terjadi apabila barier permiabilitas (epitelisasi terbentuk) dan pembentukan kembali jaringan dermis. Ciri fase proliferasi adalah angiogenesis, epitelisasi, kontraksi luka dan deposit kolagen (Morison, 2004). Pada hari ke 7 berlangsung luka mulai menutup pada $\mathrm{P} 0-\mathrm{P} 2$, sedangkan $\mathrm{P} 3$ dan $\mathrm{P} 4$ masih terbuka. Pengamatan pada hari ke- 14 P3 dan P4 mulai menutup, namun belum sempurna.

Pengujian efektivitas ekstrak daun afrika dengan 5 perlakuan. $\mathrm{P0}$ (vaseline + adeps lanae), P1 (salep povidone iodine), P2 (salep ekstrak daun afrika 16,8\%), P3 (salep ekstrak daun afrika $28 \%$ ) dan P4 (salep ekstrak daun afrika $39,2 \%$ ). Penggunaan bahan dasar salep vaseline dan adeps lanae dengan dicampurkan dengan ekstrak daun afrika untuk memperpanjang kontak antara bahan obat dengan kulit. Vaseline flavum dapat sebagai antimikroba dan sebagai pengawet ekstrak (Handayani dkk., 2015).

Pemeriksaan mikroskopis histopatologi kulit dari segi reepitelisasi dengan menggunakan pewarnaan Hematoxylin Eosin (HE), kemudian diperiksa dibawah mikroskop trinokuler dengan perbesaran 400 kali. Hasil skor dan uji statistik dengan Kruskal Wallis menunjukkan perbedaan yang tidak signifikan $(P>0,05)$ antara kontrol dengan perlakuan.

Pemeriksaan makroskopis dari kelima perlakuan, P0 (vaseline + adeps lanae), P1 (salep povidone iodine) dan P2 (salep ekstrak daun afrika 16,8\%) merupakan yang paling bagus dalam penutupan luka. Namun diantara perlakuan dengan ekstrak daun afrika P2 (salep ekstrak daun afrika 16,8\%) paling efektif dibandingkan P3 (salep ekstrak daun afrika 28 \%) dan P4 (salep ekstrak daun afrika 39,2\%).

Kesembuhan diindikasikan dengan tertutupnya luka oleh jaringan epitel yang tingginya sama dengan kulit sekitarnya, terkelupasnya jaringan nekrotik, tidak ada erythrema, tidak ada nanah dan tidak ada krusta. Pada penelitian ini P0, P1, dan P2 memenuhi kriteria kesembuhan luka (Wibawati, 2012).

P0 (vaseline + adeps lanae) luka dapat menutup dan sembuh karena adanya self healing. Luka setiap kali akan diberi perlakuan dibersihkan dengan menggunakan $\mathrm{NaCl}$ Fisiologis. Kemudian luka ditutup agar terhindar dari mikroba. Pemilihan vaseline karena sifatnya yang hidrokarbon sehingga tidak mudah hilang ketika terkena air. Vaseline flavum juga bersifat sebagai emolient dan moisturizer yang mempertahankan kelembaban kulit. (Handayani dkk., 2015).

P1 (salep povidone iodine) luka dapat menutup dan sembuh karena povidone iodine merupakan antiseptik yang mencegah terjadinya kontaminasi mikroba pada jaringan nekrotik dan juga debrimen. Hal ini dapat membantu dalam proses kesembuhan luka pada fase inflamasi, karena apabila tahap ini terlewati lebih awal maka tahap selanjutnya akan lebih cepat dimulai dibandingkan dengan kondisi normal (Subekti, 1998).

Pengamatan mikroskopis dari gambaran hisopatologi kulit dari kelima perlakuan, P2 (salep ekstrak daun afrika 16,8\%) memiliki ratarata skor reepitelisasi yang paling bagus dibandingkan dengan kontrol dan perlakuan yang lain, namun tidak ada perbedaan yang signifikan pada analisis data statistik.

Zat aktif yang ada di dalam daun afrika (Vernonia amygdalina) adalah flavonoid, tanin, antioksidan dan saponin. Zat-zat tersebut memiliki manfaat yang dapat menunjang kesembuhan luka (Ruslim dkk., 2017).

Flavonoid sebagai antioksidan kuat yang dapat mengurangi lipid peroksidasi yang dapat membantu dalam proses reepitelisasi dan antimikroba. Penurunan lipid perosidadi dalam flavonoid dapat mencegah nekrosis, memperbaiki vaskularisasi dan meningkatkan viabilitas serabut kolagen (Agarwal et al., 2009).

Saponin meningkatkan kemampuan reseptor TGF- $\beta$ fibroblas berikatan dengan TGF- $\beta$. TGF$\beta$ merupakan faktor pertumbuhan yang diperlukan fibroblas dalam mensitesis kolagen, sehingga flavonoid, saponin dan tanin diduga 
memiliki peran dalam proses penyembuuhan luka (Kanzaki T dalam Rupina dkk., 2016).

Tanin bersifat antimikroba dan meningkatkan epitelisasi. Tanin juga diduga berperan dalam pengaturan transkripsi dan translasi vascular endothelial growth factor (VEGF). VEGF bertindak secara parakrin tidak hanya dalam endotel vaskular kulit, tetapi juga keratinosit dan sel imun yang memperlihatkan efek reepitelisasi dan pada saat yang sama memulihkan angiogenesis serta perfusi oksigen (Pastar et al., 2013).

Perlakuan P3 dan P4 mendapatkan hasil luka tidak segera menutup dikarenakan adanya sumbatan yang mengering dari ekstrak dan menjadi keropeng, karena konsentrasi ekstrak yang terlalu pekat sehingga terjadi sumbatan pada area luka. Ketika luka dibersihkan menjadikan luka baru pada kulit sehingga timbul perdarahan. Luka baru tersebut menjadikan proses peradangan lebih lama dan proses pembentukan jaringan baru dan kesembuhan terhambat.

Proses kesembuhan pada P3 dan P4 terhambat dapat juga disebabkan karena kadar flavonoid dan saponin dalam daun afrika terlalu tinggi karena konsentrasi kepekatan ekstrak dalam sediaan salep. Kadar flavonoid yang tinggi dapat menurunkan sifat antioksidannya (Paramita, 2016). Kadar saponin yang terlalu tinggi dapat menyebabkan permeabilitas membran sel meningkat, sehingga sel mengalami kematian (Indraswary, 2014). Kesembuhan luka terhambat juga dapat terjadi karena semakin tingginya konsentrasi pada ekstrak daun afrika yang diberikan, maka efek sitotoksin yang ditimbulkan menjadi besar (Dalazen et al., 2005).

\section{KESIMPULAN}

Ekstrak daun afrika (Vernonia amygdalina) secara topikal tidak efektif dalam reepitelisasi penyembuhan luka insisi. Hal ini ditunjukkan dengan data statistik kelompok kontrol dengan perlakuan tidak ada perbedaan yang signifikan. Data hasil pemeriksaan makroskopis menunjukkan bahwa ekstrak daun afrika yang konsentrasinya terlalu pekat dapat menghambat kesembuhan luka.

\section{UCAPAN TERIMA KASIH}

Terima kasih kepada Laboratorium Program Studi Pendidikan Dokter Hewan Progam Studi Di luar Kampus Utama Universitas Airlangga di Banyuwangi yang telah memfasilitasi pelaksanaan penelitian ini.

\section{DAFTAR PUSTAKA}

Budiman, I., Derick. 2015. Aktivitas Kesembuhan Luka Rimpang Kunyit (Curcuma longa Linn.) Terhadap Luka Insisi pada Mencit Swiss-Webster Jantan Dewasa. Fakultas Kedokteran. Universitas Kristen Maranatha. Bandung.

Dalazen, P., Molon, A., Biavati, M.W., Kreuger, M.R.O. 2005. Effects of Topical Application of Extract from Vernonia scorpiodes on Excisional Wounds in Mice. Rev. Bras. Farmacogn., 15, 82-87.

Eyo, J. E., Uzoibiam, B.O., Ogbanya, K. C., Nnaji, T. O. 2014. Comparative Evaluation of Wound Healing Effects of Ocimum gratissimum, Vernonia amygdaline and Zingiber officinalis Extracts on Incision Wound Model in Rats. SILAE, 3, 44-50.

Handayani, F., Reksi, S., Henriko, N.K. 2017. Aktivitas Etanol Biji Pinang (Areca catecu L.) terhadap Penyembuhan Luka Bakar pada Kulit Punggung Mencit Jantan (Mus musculus). Jurnal Ilmiah Manuntung, 2(2), 158.

Indraswary, R. 2014. Efek Konsentrasi Buah Adas (Foeniculum vulgare Mill.) Topikal pada Epitelisasi Penyembuhan Luka Gingiva Labial Tikus Sparague Dawley in vivo. Fakultas Kedokteran Gigi. Universitas Islam Sultan Agung. Semarang. 
Jayalindri, N. L. G. L., Edward, N., Jimmy, P., Robert, A. B. 2016. Uji Efektivitas Ekstrak Melati (Jasmine sambac) pada Penyembuhan Luka Insisi Kelinci (Oricotalagus cuniculus). Jurnal eBiomedik, 4(1).

Morison, M. J. 2004. Manajemen Luka. EGJ, 14.

Nabella, S. A. 2017. Efektivitas Gel Ekstrak Daun Binahong (Anrendera cordifolia (Ten.) Steenis) pada Luka Insisi Mencit (Mus musculus) Melalui Pengamatan Panjang Area Luka dan Penyembuhan Luka. Fakultas Kedokteran Hewan Universitas Airlangga, 3.

Nafiu, A. B., Akinwale, O.C., Owoleye, B. V. 2016. Histomorphological Evaluation of Wound Healing-Comparison between Use of Honey and Vernonia Amygdalina Leaf Juice.Nigeria. Trop. J. Health Sci., 23(3), 10-11.

Paramita, A. 2016. Pengaruh Pemberian Salep Ekstrak Daun Binahong (Anredera cordifoila (Ten) Steenis) Terhadap Kepadatan Kolagen Tikus Putih (Rattus novergicus) yang mengalami luka bakar [Skripsi]. Fakultas Kedokteran Hewan. Universitas Airlangga. Surabaya. 7-25.

Pastar, I., Stojadinovic, O., Yin, N. C., Ramirez, H., Aron, G. N. 2013. Epithelization in Wound Healing a Comperehensive Review. Advances in Wound Care, 3 (7), 451.

Putri, S. A., Nugraha, S., Tjoekra, R. 2014. Efek Ekstrak Etanol Daun Cocor Bebek (Kalanchoe pinnata [Lam] Pers.) terhadap Waktu Penyembuhan Luka Sayat pada Tikus putih Jantan Galur Wistar. Fakultas Kedokteran: Universitas Islam Bandung, 886-887.

Saputri, R., Aristha, N. P. 2017. Potensial Ekstrak Etanol Herba Lampasau (Diplazium esculentum SWART) Sebagai Penyembuh Luka Sayat pada Kulit Tikus. Jurnal Borneo J. Pharmascientech, 1(1), 16.

Sastrawan, N. K. L., Wardhita, A. A. G. J., Dada, I. K. A., Sudimartini, L. M. 2016. Perbandingan Kecepatan Kesembuhan Luka Insisi yang Diberi Amoksilin-Deksametason dan Amoksilin-Asam Mefenamat pada Tikus Putih (Rattus novergicus). 5(2), 129-144.

Subekti, D. T. 1998. Perbandingan antara Alantonin (5 Ureidohydantoin) dengan Betadine ${ }^{\circledR} \quad$ (Povidone iodine) untuk Pengobatan Luka Insisi. Seritagiologi, 4(4), 1998.

Suckow, M. A., Weisbroth, S. H., Franklin, C. L. 2006. The Laboratory Rat American College of Laboratory. Elsevier Academic Press. USA. 655 .

Udochukwu, U., Omeje, F. I., Uloma, I. S., Oseiwe, F. D. 2015. Phytochemical Analysis of Vernonia amygdalina and Ocimum gratissimum Extracts and Their Antibacterial Activity on Some Drug Resistant Bacteria, 3(5), 230.

Wibawati, P. A. 2012. Pengaruh Ekstrak Daun Sirih Merah (Piper betle Var. Rubrum) Terhadap Waktu Kesembuhan Luka Insisi yang diinfeksi Staphylococcus aureus pada Tikus putih Putih [Skripsi]. Fakultas Kedokteran Hewan. Universitas Airlangga. 